\title{
Catecholaminergic Cell Lines from the Brain and Adrenal Glands of Tyrosine Hydroxylase-SV40 T Antigen Transgenic Mice
}

\author{
Chitra Suri, ${ }^{1, a}$ Brenda P. Fung, ${ }^{2}$ Arthur S. Tischler, ${ }^{3}$ and Dona M. Chikaraishi ${ }^{1,4}$ \\ ${ }^{1}$ Neuroscience Program and Departments of ${ }^{2}$ Medicine, ${ }^{3}$ Pathology, and ${ }^{4}$ Microbiology and Molecular Biology, Tufts \\ University School of Medicine, Boston, Massachusetts 02111
}

\begin{abstract}
Brain (CATH.a) and adrenal (PATH.1 and PATH.2) cell lines have been established that synthesize abundant dopamine and norepinephrine and express the appropriate catecholaminergic biosynthetic enzymes, tyrosine hydroxylase (TH) and dopamine $\beta$-hydroxylase. The lines were derived from TH-positive tumors in transgenic mice carrying the SV40 T antigen oncogene under the transcriptional control of 773 base pairs of $5^{\prime}$ flanking sequences from the rat TH gene. Although the lines continue to express $T$ antigen, they exhibit neuronal properties such as neurofilaments and synaptophysin and lack glial intermediate filaments. Although in vivo TH is only expressed in postmitotic neurons in the CNS, the CATH.a line demonstrates that TH expression and continued cell division are not incompatible after oncogenic transformation.
\end{abstract}

[Key words: noradrenergic cell lines, tyrosine-hydroxylase, SV40 T antigen, transgenic mice, brain tumor, catecholamines]

Immortalized cell lines of differentiated neuronal cell types can be valuable research tools because they provide homogeneous sources of single cell types. They can be used to elucidate mechanisms of induction without the complicating presence of nontarget cells, a situation impossible to achieve in vivo or in mixed primary cultures. They can also serve as sources of cell-specific molecules, as recipients for such molecules in gene transfer experiments, or as sources for cell transplants into the nervous system. Neuronal cell lines from the CNS are especially valuable since it is difficult to prepare pure populations of primary neurons. In addition, few differentiated cell lines originating from the CNS exist.

Neuronal cell lines have been generated by four methods: (1) from spontaneously arising or chemically induced tumors, (2) by fusion of neurons to neuroblastoma cells, (3) by retroviral infection of neural precursor cells, and (4) by the use of oncogenes driven by cell-specific promoters that direct tumorigenesis

Received June 5, 1992; revised Sept. 21, 1992; accepted Sept. 30, 1992.

This work was supported by NIH Grants NS22675 and NS29679 and J. Howard Pew Freedom Trust (D.M.C.) and by CA27808 (A.S.T.). We thank Dr. B. Upchurch for advice on the creation of transgenic mice; Dr. S. Roffler-Tarlov, Ms. B. Martin, and Mr. C. Jackson for the use of the HPLC system; Dr. J. Wang for assisting with the Western analysis and for providing the rat brain synaptosomal preparation; and Dr. D. Beitner-Johnson for photographic advice.

Correspondence should be addressed to Dona $M$. Chikaraishi, Neuroscience Program, Tufts University School of Medicine, 136 Harrison Avenue, Boston, MA 02111.

a Present address: Regeneron Pharmaceuticals, Inc., 777 Old Saw Mill River Road, Tarrytown, NY 10591.

Copyright (C) 1993 Society for Neuroscience $0270-6474 / 93 / 131280-12 \$ 05.00 / 0$ to defined neurons in transgenic mice. Although many cell lines have been derived from spontaneous or induced tumors, the majority are relatively undifferentiated (Spengler et al., 1973; Schubert et al., 1974; Waymire and Gilmer-Waymire, 1978). Many have a mixed neuronal and glial phenotype characteristic of very immature cell types. The PC12 cell line (Greene and Tischler, 1976) and some mouse C-1300 subclones (Amano et al., 1972) do exhibit some differentiated properties. However, these lines are derived from the PNS. Somatic cell hybrids offer the potential for obtaining immortalized cells with a well-differentiated phenotype, since mature CNS neurons can theoretically be used as fusion partners. Unfortunately, the success rate of such fusions is low and most rescarchcrs have rclied on cmbryonic neuronal tissue to obtain hybrids that resemble mature neurons to varying degrees (Lee et al., 1990; Choi et al., 1991). An additional major drawback of somatic cell hybrids is the extent to which the neuroblastoma partner may influence the resulting hybrid, since the neuroblastoma parent is of PNS origin. This is of concern because hybrids contain additional chromosomes derived from the neuroblastoma parent and often lose those from the non-neuroblastoma parent. Recently, mesencephalic hybrid lines have been established by the fusion of embryonic mesencephalic cells with a neuroblastoma line (Choi et al., 1991; Crawford et al., 1992). Although these lines resemble mature midbrain neurons, they synthesize not only dopamine (DA) but also norepinephrine (NE), which is surprising since mature mesencephalic cells are exclusively dopaminergic (Bjorklund and Lindvall, 1984). Some of these problems can be circumvented by generating cell lines with retroviral or transgenic technologies. Retroviral infection of primary neuronal cultures can result in neuronal cell lines capable of undergoing differentiation under appropriate conditions (Cepko, 1989; Lendahl and McKay, 1990). Since the virus requires at least one round of cell division in order to integrate into the host's genome, this approach has been largely limited to the immortalization of cycling precursor cells (Fredericksen et al., 1988; Ryder et al., 1990). Transplantation experiments have shown that these precursor cells retain their plasticity when implanted into a developing brain, giving rise to cells appropriate for the site of implant (Renfranz et al., 1991; Snyder et al., 1992). Retroviral infection has thus been of greatest use for lineage analyses and other developmental studies.

The most direct approach to create cell lines of defined neuronal cell types utilizes tissue-specific promoter elements to direct oncogene expression in transgenic mice (Cory and Adams, 1988; Jenkins and Copeland, 1989). In this way, very specific cells may be targeted. In the last few years this technique has led to the immortalization of gonadotropin-releasing hormone 
(GnRH)-expressing and retinal amacrine neurons (Hammang et al., 1990; Mellon et al., 1990), as well as for differentiated cells of many non-neuronal tissues (Hanahan, 1989). Since the target cell destined for transformation is determined by the regulatory promoter elements used, in theory tumors can be induced in any cell type for which specific regulatory elements are available. For the most part, tumors have been observed in the appropriate tissues, although ectopic expression does occur (Behringer et al., 1988; Cory and Adams, 1988).

We have used the upstream elements of the rat tyrosine hydroxylase (TH) gene to drive the SV40 T antigen (Tag) oncogenc to generate tumors in the TH-producing cells of the CNS and PNS. TH is the first and the rate-limiting enzyme in the catecholamine biosynthetic pathway. It converts L-tyrosine into dihydroxyphenylalanine (L-dopa), from which are sequentially synthesized DA, NE, and epinephrine (E) such that all catecholamine-producing cells express $\mathrm{TH}$. The 5' upstream regulatory region of the $\mathrm{TH}$ gene has been well studied (Lewis et al., 1987; Cambi et al., 1989; Fader and Lewis, 1990; Gizang-Ginsberg and Ziff, 1990; Yoon and Chikaraishi, 1992; Banerjee et al., 1992; Fung et al., 1992), and elements necessary for cellspecific expression in cultured cells (Yoon and Chikaraishi, 1992; Fung et al., 1992) and in transgenic mice (Kaneda et al., 1991; Banerjee et al., 1992) have been defined. The expression of TH in the nervous system has been well established. It has a specific tissue distribution in the CNS in discrete nuclei mainly in the olfactory bulb (OB), midbrain, and brainstem regions (Bjorklund and Lindvall, 1984). In the PNS it is most abundant in the chromaffin cells of the adrenal medulla and in sympathetic ganglia (Rothman et al., 1980). In the rodent CNS (excluding the $\mathrm{OB}$ ), the total number of TH-producing cells is less than 70,000 , scattered across a number of sites, which makes the isolation of pure populations of TH-positive cells very difficult. Since TH in the CNS is expressed only in postmitotic neurons (Specht et al., 1981), immortalization of TH-expressing neurons using retroviruses is unlikely.

SV40 Tag has been shown to induce tumors in a wide variety of tissues. Though other oncogenes such as c-myc and H-ras have been demonstrated to induce tumors, they are relatively restricted in the types of tissues that they can transform (Davis et al., 1987; Sinn et al., 1987). SV40 Tag, on the other hand, has been successful in inducing tumors in many cell types and, in particular, has been used to generate tumors in endocrine and neural tissues. For example, endocrine pancreatic tumors have been induced when Tag was under the control of the promoters for insulin (Hanahan, 1985), glucagon (Efrat et al., 1988), and vasoactive intestinal peptide (VIP; Murphy et al., 1987); anterior pituitary tumors were produced with the promoters for VIP (Murphy et al., 1987) and glycoprotein hormone $\alpha$-subunit (Windle et al., 1990); retinal and adrenal gland tumors were obtained with the phenylethanolamine $N$-methyl transferase (PNMT) promoter (Baetge et al., 1988) and hypothalamic tumors have been generated with the GnRH promoter (Mellon et al., 1990).

We report here the immortalization of cells from the brain and adrenal glands of transgenic mice bearing SV40 Tag under the control of 773 base pairs (bp) of the upstream regulatory region of the rat $\mathrm{TH}$ gene. We have established three cell lines that possess a neuronal phenotype, indicated by the presence of neurofilament (NF) proteins and the absence of glial fibrillary acidic protein (GFAP). The lines are strongly catecholaminergic, synthesizing high levels of TH enzyme and producing both DA and NE. They also contain synaptophysin, a protein specific to small synaptic vesicles in neurons and related small vesicles in neuroendocrine cells (Navone et al., 1986; Johnston et al., 1989).

\section{Materials and Methods}

Plasmid construction. A Nar-Nar fragment ( -19 to 2562) was deleted from -4.8 THCAT (Cambi et al., 1989) and replaced with a synthetic oligonucleotide containing TH sequences from -19 to +10 followed by three unique sites (SmaI, NruI, SaiI) and NarI half-sites at either end. The resulting plasmid, 4.8 TH0, contains 4.8 kilobases $(\mathrm{kb})$ of upstream TH and $10 \mathrm{bp}$ of TH $5^{\prime}$ untranslated region followed by the Smal, Nrul, and Sall sites. The plasmid retains an ampicillin-resistance gene and a colE1, origin of replication. A $2.7 \mathrm{~kb}$ StuI-BamH 1 fragment from wild-type SV40 DNA (Fiers et al., 1978) was blunt ended and inserted into the unique SmaI site of $4.8 \mathrm{THO}$ to generate 4.8THTag. Digestion with XhoI and SalI yielded a linear piece of DNA containing the complete coding sequence for Tag $(2.7 \mathrm{~kb})$ under the control of $-773 \mathrm{bp}$ of TH. The DNA was purified from agarose gels by the sodium perchlorate method (Chen and Thomas, 1980) and resuspended at a concentration of $5 \mathrm{ng} / \mu \mathrm{l}$ for injections.

Transgenic mice. The procedures were done essentially as described by Hogan et al. (1986). DNA was injected into the male pronucleus of recently fertilized eggs from B6/D2 F1 donor mice (Taconic Labs). Following an overnight incubation at $37^{\circ} \mathrm{C}$, the two-cell embryos were implanted into the oviducts of pseudopregnant CD-1 females (Charles River Labs.). Pups bearing the transgene were identified by a tail blot in which DNA from a tail segment was isolated, bound to nitrocellulose filters, and probed with a radiolabeled DNA fragment corresponding to Tag. Pups were screened for the presence of an un-rearranged transgene by Southern analysis (Maniatis et al., 1982).

Cell culture. Tumors were removed under sterile conditions and cut into small pieces. These were mechanically triturated in RPMI 1640 medium containing $0.018 \%$ type I collagenase (Worthington Biochemical Corp.) with $0.2 \%$ bovine serum albumin (Sigma) and placed at $37^{\circ} \mathrm{C}$ for $20-25 \mathrm{~min}$. The reaction was stopped by the addition of serumcontaining medium, and the cells were triturated again and pelleted. They were then plated onto tissue culture plastic and grown in medium containing RPMI 1640 supplemented with $8 \%$ horse serum (Hyclone), $4 \%$ fetal bovine serum (GIBCO), $1 \%$ penicillin-streptomycin (stocks of $10,000 \mathrm{U} / \mathrm{ml}$ penicillin $\mathrm{G}$ and $10,000 \mu \mathrm{g} / \mathrm{ml}$ streptomycin sulfate; Irvine Scientific) and $20 \mathrm{U} / \mathrm{ml}$ nystatin (GIBCO). The mixed primary cultures were passaged once a week using $0.12 \%$ trypsin without EDTA (Irvine Scientific). Even in primary cultures, few glial or fibroblastic cells were evident. For cloning purposes, cells were grown at a low density and glass cylinders were used to isolate individual colonies that were triturated to clumps of $1-10$ cells in the presence of $0.12 \%$ trypsin (without EDTA), and replated at cloning densities. This procedure was performed three times. A more rigorous treatment to obtain only single cells was not successful even when different substrata or conditioned media from healthy cultures were used for culturing.

PATH.1 was grown on dishes coated with poly-L-lysine (Sigma) at a concentration of $100 \mu \mathrm{g} / \mathrm{ml}$ to improve attachment. This procedure did not affect the properties of the cell line.

Immunohistochemistry. Tissues and tumors were immersed in Bouin's fixative $(75 \mathrm{ml}$ saturated picric acid, $25 \mathrm{ml} 37 \%$ formaldehyde, $5 \mathrm{ml}$ glacial acetic acid) for $4 \mathrm{hr}$ to overnight depending on tissue thickness, after which time they were treated as required for cryostat or paraffin sectioning. Cryostat $(9-12 \mu \mathrm{m})$ and paraffin $(6 \mu \mathrm{m})$ sections were usually placed on $0.01 \%$ poly-t-lysine-coated slides. Cell lines were grown on poly-L-lysine-coated glass coverslips placed in a 24-well plate, and were fixed by a 15 min exposure to Bouin's fixative.

Triton X-100 (0.3\%) in potassium phosphate-buffered saline (T/KPBS) was used for permeabilization and was present until the enzymatic reaction was performed in the last step of the procedure. Hydrogen peroxide (1\%) in absolute methanol was added to the sections or cells for $20 \mathrm{~min}$ to reduce background due to endogenous peroxidase activity. For Tag detection, tissue sections were treated with $0.003 \%$ bacterial protease XXIV (Sigma) in T/KPBS for $15 \mathrm{~min}$. This treatment partially digested the cellular proteins, including Tag, thereby better exposing the antigens. Since the proteolytic treatment tended to increase background staining, these sections were routinely blocked with avidin followed by biotin (blocking kit, Vector Labs). These solutions were used undiluted and as provided by the supplier. All sections and cells were incubated in $2 \%$ normal goat serum (Vector Labs) and $1 \%$ Carnation nonfat dry 
milk in T/KPBS for 30 min to block nonspecific binding prior to addition of primary antibody.

Primary antibody incubations were at $4^{\circ} \mathrm{C}$ for $1-3 \mathrm{~d}$ depending on the antigen. TH antiserum (Eugene Tech.) was a rabbit polyclonal antiserum against bovine TII. It was used at a dilution of 1:250 or 1:500, depending on the batch. Tag antiserum (rabbit polyclonal) was a gift from Dr. D. Hanahan (UCSF) and was used at a 1:5000 dilution for tissue sections and at a 1:10,000 dilution for cells. Anti-synaptophysin was a rabbit polyclonal against the rat antigen. It was a gift of Dr. J. Wang (Tufts Univ.) and was used at a dilution of 1:200. Antibodies against the medium chain of NF and GFAP were gifts of Dr. V. Lee (Univ. Penn.). Anti-NF, a mouse monoclonal, was used at a dilution of $1: 10$, and anti-GFAP, a rat monoclonal, at a dilution of $1: 100$. The buffer for dilutions contained 1\% Carnation nonfat dry milk in T/KPBS with $0.02 \%$ sodium azide. Sections were covered with glass coverslips to prevent drying. Biotinylated secondary antibodies (goat anti-rabbit, horse anti-mouse, and goat anti-rat) were obtained from Vector Labs and used at a dilution of 1:200 in T/KPBS with 1\% Carnation milk for $2 \mathrm{hr}$ at room temperature. Antibody reactions were visualized with an enzymatic assay utilizing the peroxidase enzyme linked to avidin (ABC kit, Vector Labs). Sections and cells were incubated in the ABC mix for $1 \mathrm{hr}$ at room temperature. Diaminobenzidine (at $40 \mathrm{mg} / 100 \mathrm{ml}$ in Trisbuffered saline, $\mathrm{pH} 7.4$ ) and hydrogen peroxide (at $0.003 \%$ ) acted as substrates and $\mathrm{NiCl}$ (at $0.04 \%$ ) as an enhancer for the reaction, which was allowed to proceed until the blue-black color was visible, but not more than $20 \mathrm{~min}$. All sections and cells were dehydrated in ethanol and xylene, and permanently mounted with Permount (Fisher Scientific).

TH enzyme activity (modified from Rittenhouse et al., 1988). Cells were grown to $70 \%$ confluency on $65 \mathrm{~mm}$ plates. They were rinsed twice with cold phosphate-buffered saline (PBS), scraped off, and pelleted at $10,000 \mathrm{rpm}$ for $10 \mathrm{~min}$. The pellet was homogenized in $150 \mu \mathrm{l}$ of a buffer containing $0.1 \%$ Triton X-100 in 5 mm Tris (pH 6.0) and recentrifuged. The supernatant ( $10 \mu \mathrm{l}$ aliquots) was assayed in duplicate at $37^{\circ} \mathrm{C}$ for $6 \mathrm{~min}$ in a reaction mix consisting of $200 \mathrm{mM} \mathrm{KHPO}{ }_{4}(\mathrm{pH}$ 6.0), $3.2 \mathrm{~mm} 6$-methyl-5,6,7,8-tetrahydropterin, $80 \mu \mathrm{M}$ L-tyrosine, 300 $\mu \mathrm{M}$ brocresine, $40 \mathrm{mM} \beta$-mercaptoethanol, and $2 \times 10^{5} \mathrm{U} / \mathrm{ml}$ catalase. Epinephrine ( $25 \mathrm{pmol})$ in $0.1 \mathrm{~mm}$ EDTA and $0.5 \mathrm{~m}$ Tris (pH 8.6) was used to stop the reaction. Catecholamines were allowed to bind to acidwashed alumina for $15 \mathrm{~min}$ with constant shaking. The alumina was then pelleted and washed twice with $0.1 \mathrm{M} \mathrm{NaHSO}_{3}$ in $0.5 \mathrm{M}$ Tris (pH 8.6). The bound catechols were eluted with $0.1 \mathrm{M} \mathrm{H}_{3} \mathrm{PO}_{4}, 0.1 \mathrm{~mm}$ EDTA and quantitated by HPLC. Protein content in an aliquot of the supernatant used for the assay was determined by the method of Lowry et al. (1951).

DBH enzyme activity (modified from Sperk et al., 1980). Cells were grown and pelleted as above. They were sonicated after resuspension in cold 50 mм sodium acetate $\mathrm{pH} 6.0$ with $1 \%$ Triton $\mathrm{X}-100$. After one freeze-thaw cycle, they were centrifuged at $12,000 \mathrm{rpm}$ for $10 \mathrm{~min}$. Protein content in the supernatant was measured by the method of Lowry et al. (1951). Protein $(10 \mu \mathrm{g})$ was added to $100 \mu \mathrm{l}$ of $1 \%$ concanavalin A Sepharose $4 \mathrm{~B}$ beads in $50 \mathrm{~mm}$ sodium acetate (pH 5.5). Dopamine $\beta$-hydroxylase (DBH) was allowed to adsorb to the beads for $15 \mathrm{~min}$ at $4^{\circ} \mathrm{C}$, and the beads were pelleted at $12,000 \mathrm{rpm}$ for $3 \mathrm{~min}$. They were washed three times with ice water and resuspended in 200 $\mu l$ of 50 mm sodium acetate ( $\mathrm{pH} 5.5)$. The enzymatic assay was performed at $37^{\circ} \mathrm{C}$ for $30 \mathrm{~min}$ using $100 \mu \mathrm{l}$ of DBH-bound beads in a final reaction volume of $200 \mu \mathrm{l}$. The reaction mix contained $3 \mathrm{~mm}$ dopamine, $4 \mathrm{~mm}$ ascorbic acid, $40 \mathrm{~mm}$ fumarate, $0.6 \mathrm{~mm}$ pargyline, $700 \mathrm{U}$ of catalase, $3 \mu \mathrm{M}$ copper sulfate, and $50 \mathrm{~mm}$ sodium acetate ( $\mathrm{pH} 5.5$ ). The reaction was stopped by chilling on ice and with the addition of 0.5 volumes of $2 \mathrm{M}$ Tris ( $\mathrm{pH} \mathrm{8.6)}$. The catecholamines were extracted with alumina as described for the TH assay and detected by HPLC.

$H P L C$. A C-18 reverse-phase column (Beckman Co.) was used in combination with an electrochemical detector (Waters). The mobile phase contained 7.5\% methanol, $50 \mathrm{mM} \mathrm{NaH}_{2} \mathrm{PO}_{4}(\mathrm{pH} \mathrm{3.6)}, 0.387 \mathrm{~mm}$ sodium octyl sulfate, and $0.1 \mathrm{~mm}$ EDTA.

Northern analysis. Cells were grown on $150 \mathrm{~mm}$ plates. PolyA ${ }^{+}$RNA was prepared using the Fast Track mRNA isolation kit (Invitrogen) Northerns were performed as described (Maniatis et al., 1982) using 2 $\mu \mathrm{g}$ of polyA ${ }^{+}$RNA per lane of a $1 \%$ formaldehyde-agarose gel. Molecular weight markers ranging in size from 0.24 to $9.49 \mathrm{~kb}$ were purchased from Bethesda Research Labs. After electrophoresis the gel was immersed in $0.05 \mathrm{~N} \mathrm{NaOH}$ for $20 \mathrm{~min}$, rinsed in DEPC-treated $\mathrm{H}_{2} \mathrm{O}$, and equilibrated in $1 \times \operatorname{SSC}$ buffer $(0.15 \mathrm{M} \mathrm{NaCl}, 15 \mathrm{~mm}$ sodium citrate, $\mathrm{pH}$
7.0). RNA was transferred to a Genescreen membrane by passive capillary flow for at least $20 \mathrm{hr}$, and cross-linked to the membrane by exposure to $1600 \mathrm{~J}$ of $\mathrm{UV}$ radiation. The membrane was prehybridized for at least $5 \mathrm{hr}$ at $42^{\circ} \mathrm{C}$ in a buffer containing $50 \%$ formamide, $5 \times \mathrm{SSC}$, $0.1 \%$ SDS, $0.1 \%$ sodium pyrophosphate, $120 \mu \mathrm{g} / \mathrm{ml}$ salmon sperm DNA, $10 \times$ Denhardt's reagent, and $10 \%$ dextran sulfate. Hybridization was done overnight under similar conditions in the presence of a radioactive probe. The membrane was washed at $65^{\circ} \mathrm{C}$ under stringent conditions and exposed to Kodak XOMat film for autoradiography.

Sources of DNA for making radiolabeled probes were as follows: TH plasmid RR 1.2, Cambi et al. (1989); NF plasmid, gift of Dr. N. Cowan, NYU; and PNMT plasmid, gift of Dr. E. Weisberg, Univ. of Pittsburgh. DNA probes with an average specific activity of 180 million $\mathrm{cpm} / \mu \mathrm{g}$ were made by random priming of the intact TH and PNMT plasmids (Maniatis et al., 1982). NF RNA probe of a similar specific activity was made according to standard protocols.

Determination of total catecholamines. Cells were grown on $65 \mathrm{~mm}$ plates, washed twice with ice-cold PBS, and scraped off mechanically. The cell pellet was homogenized in $0.1 \mathrm{~N} \mathrm{HClO}_{4}$ and $1 \mathrm{mM}$ EDTA. After centrifugation for $10 \mathrm{~min}$ at $10,000 \mathrm{rpm}$, the supernatant was neutralized with $0.5 \mathrm{vol}$ of $2 \mathrm{M}$ Tris $(\mathrm{pH} \mathrm{8.6)}$ and adsorbed to acidwashed alumina. Following this step, the procedure was as described for the TH enzyme assay. In order to measure the amount of catecholamines in the supernatant, cells were fed with fresh media $24 \mathrm{hr}$ before the catecholamines were extracted.

Western blots. Cell pellets were resuspended in electrophoresis buffer (3\% SDS, 5\% glycerol, $0.064 \mathrm{~m}$ Tris pH 6.8, 2\% $\beta$-mercaptoethanol), placed in a boiling water bath for $5 \mathrm{~min}$, and stored at $-70^{\circ} \mathrm{C}$. Protein content in an aliquot was measured by the method of Lowry et al. (1951). One hundred microliters of the mix (containing $67 \mu \mathrm{g}$ total protein) were loaded per lane onto an $8 \%$ acrylamide-SDS gel. The proteins were transferred electrophoretically to an Immobilon membrane (Millipore). Nonspecific binding was reduced by incubating the membrane for $1 \mathrm{hr}$ in Tris-buffered saline containing 0.1\% Tween-20 (TBST) and 3\% Carnation nonfat dry milk. It was then exposed to anti-synaptophysin serum at a 1:500 dilution in the same buffer for $1.5 \mathrm{hr}$ at room temperature. Following three washes in TBST buffer with 3\% milk, horseradish peroxidase linked to donkey anti-rabbit antibody was added at a 1:2000 dilution for $40 \mathrm{~min}$ at room temperature. The membrane was washed three times in TBST and the bands visualized by an ECL detection system (Amersham)

\section{Results}

TH-expressing tumors in transgenic mice bearing a TH-Tag transgene. A $783 \mathrm{bp}$ region of the rat $\mathrm{TH}$ gene, containing 773 bp of $5^{\prime}$ upstream DNA and the first 10 bp of untranslated mRNA, was linked to the complete coding region of the wildtype SV40 Tag (Fiers et al., 1978). The hybrid gene contained the mRNA initiation site at +1 from the TH gene and the translation start site from the Tag sequence that also provided the natural splice sites and the polyadenylation site. This linearized construct, devoid of plasmid sequences, was injected into fertilized B6/D2 F1 ova. Seven of the 21 pups contained the transgene in their DNA. Southern analysis showed deletions in the transgene in two of these founders (data not shown), which were therefore discarded; the other founders contained one to five copies of un-rearranged TH-Tag transgene. One female founder, \#17, died at 10 weeks of age during pregnancy from a massive adrenal tumor that occupied the top left quadrant of the abdominal cavity. The other four founders bred successfully but mice in three lineages were nonexpressors. The remaining founder, $\# 20$, established a lineage in which the progeny consistently developed brain tumors. The age of the animals at the onset of tumors varied from 15 weeks to 8.5 months. It is likely that all animals of this lineage will develop tumors with time. In all cases the tumor-bearing mice demonstrated motor difficulties, and exhibited a hunched posture and an enlarged head. Upon dcath, the mice were found to have tumors on the ventral 

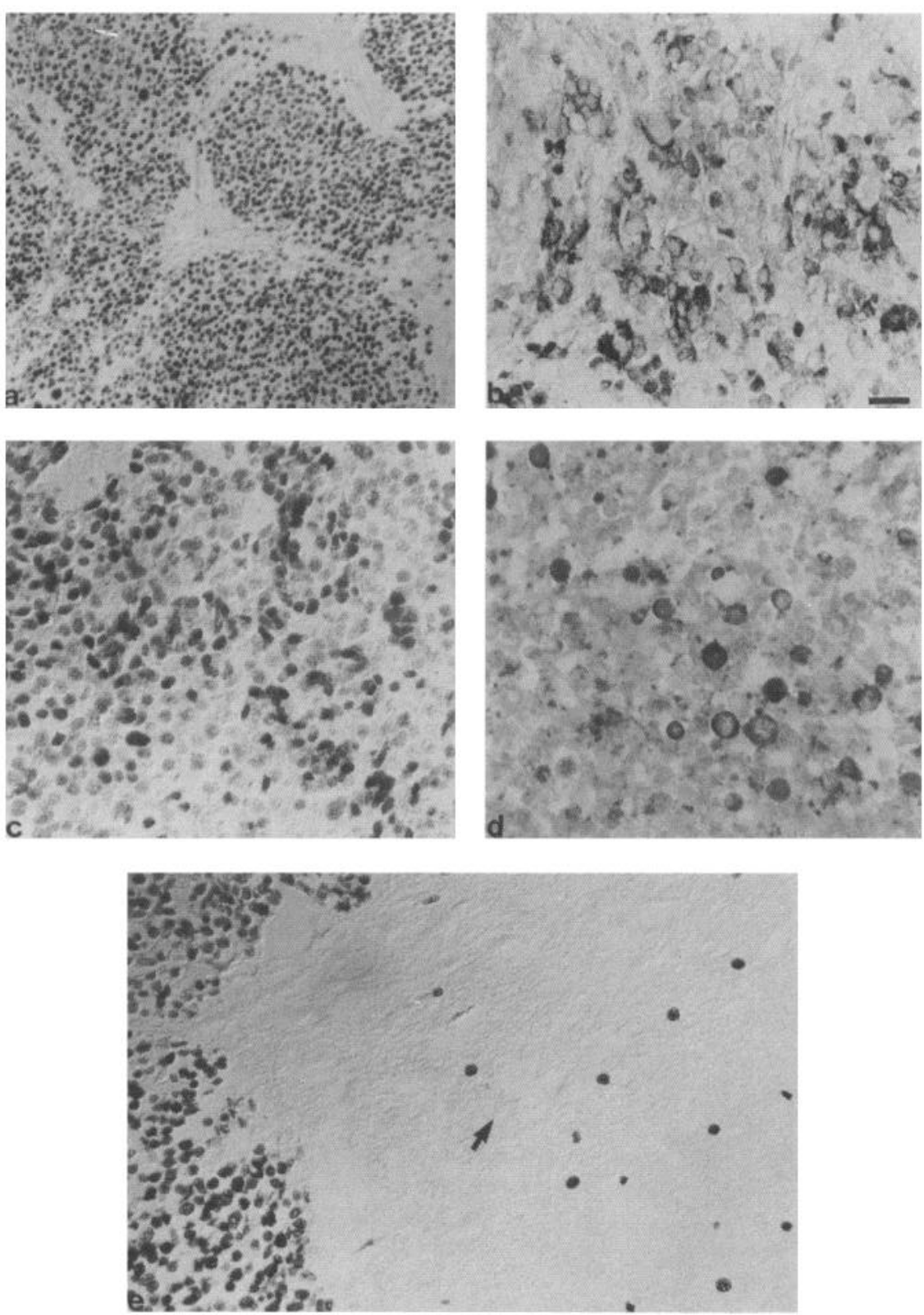

Figure 1. Tag and TH staining in tumor sections: Tag in the nuclei $(a)$ and $\mathrm{TH}$ in the cytoplasm $(b)$ of brain tumor cells, Tag $(c)$ and TH $(d)$ in adrenal tumor cells, and boundary between tumor and normal brain tissue $(e)$. Note the isolated Tag-positive nuclei in the adjacent nontumor region in $e$; arrow indicates an unstained nucleus in this region. $a, b$, and $e$ are $6 \mu \mathrm{m}$ paraffin sections, and $c$ and $d$ are $9 \mu \mathrm{m}$ cryostat sections. Immunochemical reactions are as described in Materials and Methods. Scale bar, $20 \mu \mathrm{m}$ for $b-e ; a$ is at a lower magnification to show the lobular nature of the tumors. aspect of the brain, centered about the midbrain and rostral brainstem. No organ other than the brain and adrenal glands developed a tumor in any of the transgenic mice, nor was there Tag staining in any of the other organs.

Sections from the tumors were either treated for immunohistochemical analysis or placed in tissue culture medium. Morphologically, both the adrenal and brain tumors resemble neuroblastomas composed of small, densely packed, undifferentiated cells with scant cytoplasm. Figure 1 illustrates a typical staining pattern for TH and Tag proteins in adrenal and brain tumor sections. Whereas Tag can be seen in all the cells of the tumor, albeit at a variable intensity, TH is patchy in its distribution, appearing primarily in cells within a group or nodule. Interestingly, in lineage 20, expression of Tag is also observed in scattered cell nuclei in nontumorigenic brain areas that lack THpositive cell bodies. In these areas, which include the midbrain, brainstem, and specific layers in the cortex and cerebellum, stained nuclei can be seen intermingled with unstained cells (Fig. 1e). This ectopic distribution of the Tag protein was also observed in the brains of siblings that had not yet developed a tumor.

With $-773 \mathrm{bp}$ of $\mathrm{TH}$, therefore, Tag was observed in regions that were both appropriate (brain and adrenal glands) and inappropriate (non-TH-producing brain cells). However in some TH-positive regions like the $\mathrm{OB}$ and superior cervical ganglia (SCG), Tag expression was never detected, suggesting that 773 bp of $5^{\prime}$ TH information is not sufficient for a completely appropriate in vivo expression.

Derivation of immortalized cell lines. Primary tumor cells from the adrenal tumor of founder female 17 and from a brain tumor of a male offspring of founder 20 were grown as mixed cultures for 3-5 months. Cell lines were then isolated from both the adrenal and brain tumor cultures as described in Materials and Methods. These lines were derived by isolation of individual clumps of 1-10 cells that were plated at cloning density. The progeny of each clump were subjected to at least two additional 

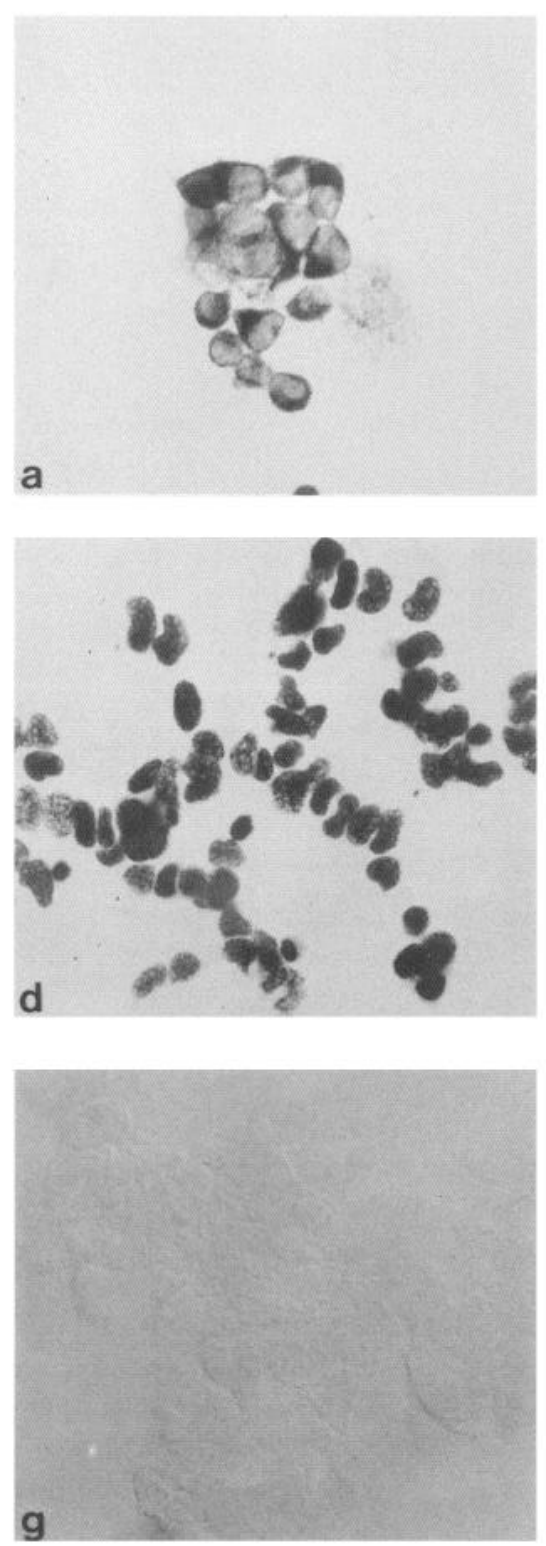
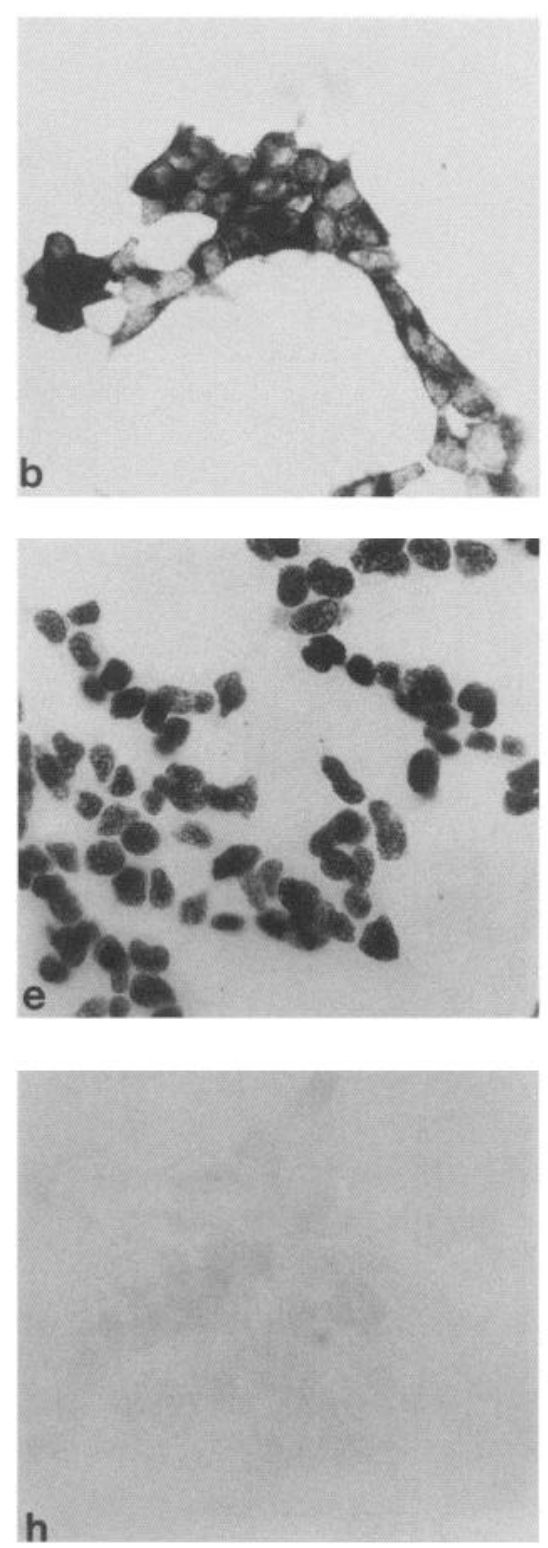
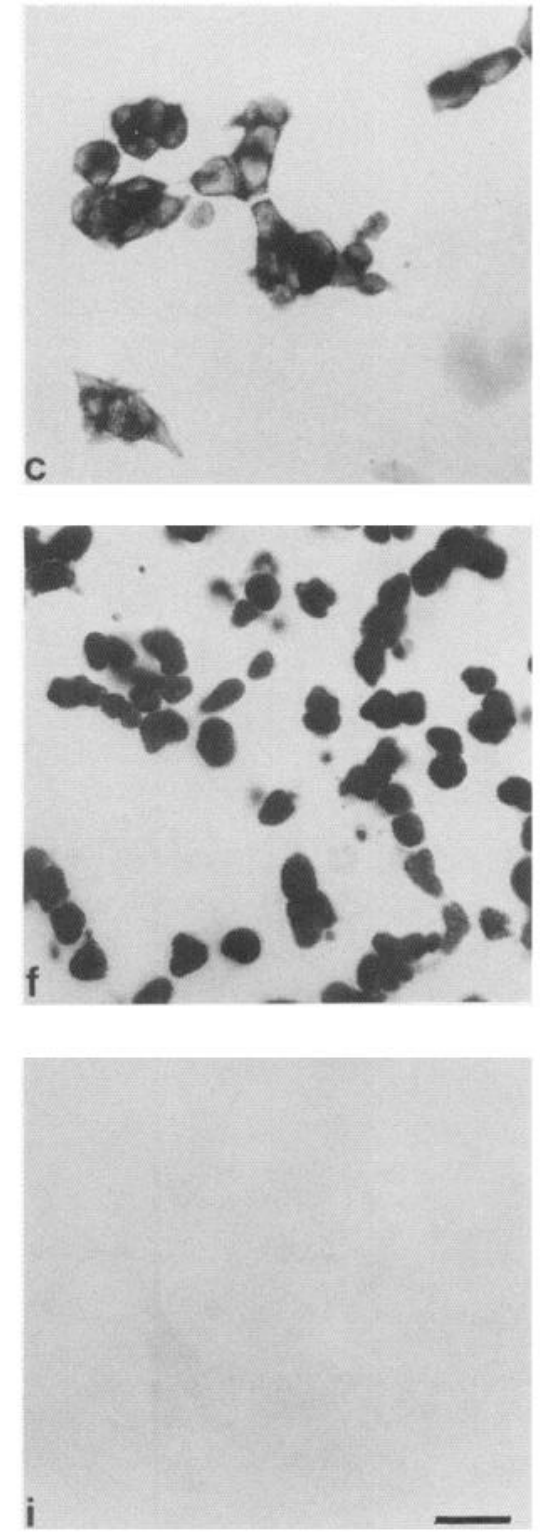

Figure 2. TH and Tag staining in cell lines: TH staining in CATH.a $(a)$, PATH.1 $(b)$, and PATH.2 $(c)$; Tag staining in CATH.a $(d)$, PATH.1 $(e)$, and PATH.2 $(f)$; control staining with normal goat serum in CATH.a $(g)$, PATH.1 $(h)$, and PATH.2 $(i)$. All cells were grown on poly-L-lysinecoated glass coverslips. Scale bar, $20 \mu \mathrm{m}$ for all but $g$, which is at a higher magnification to show the absence of cellular staining.

cycles of similar selection. After the first cycle, cells were tested for the presence of TH by immunochemical means. Approximately $50 \%$ of the adrenal lines and $12 \%$ of the brain lines contained TH. From the adrenal culture, two cell lines, PATH.1 and PATH. 2 (for peripheral adrenergic TH-expressing), have been studied extensively. They have been passaged at least once a week since February 1991. The brain culture yielded one strongly catecholaminergic cell line, CATH.a (for central adrenergic TH-expressing), which has been cultured since April 1991. CATH.a and PATH.2 attach well to uncoated plastic tissue culture dishes, whereas PATH.1 adheres less well to standard culture plates. All three cell lines have since been frozen in liquid nitrogen and successfully thawed.

Figure 2 shows the morphology and immunochemical staining patterns for TH and Tag in these three cell lines. All three lines grow in clumps, lack appreciable processes, and appear relatively undifferentiated, with large nuclei and scant cyto- plasm. They maintain this morphology when plated on poly-Llysine, collagen, laminin, or irradiated mouse NIH3T3 cells, or in defined media in the absence of serum. However, they stain very strongly for TH and Tag. The expected compartmentalization of $\mathrm{TH}$ and Tag is evident in that the TH antibody stains the cytoplasm, while the Tag staining is restricted to the nucleus. While Tag staining is very robust and homogeneous, staining for $\mathrm{TH}$ is typically heterogeneous and of variable intensity. The same result was obtained with both a rabbit polyclonal and a mouse monoclonal antibody against $\mathrm{TH}$. We have observed a similar heterogeneity in the PC8b cell line, a subclone of the PC12 cell line (Tank et al., 1990). The reason for this heterogeneity is not clear. To test the possibility that $\mathrm{TH}$ is expressed only in nondividing cells, cells were grown in bromodeoxyuridine (BUdR) for $1 \mathrm{hr}$ before fixation and double stained with anti-TH and anti-BUdR antibodies. A high proportion of THpositive cells was found to be BUdR=labeled (data not shown), 

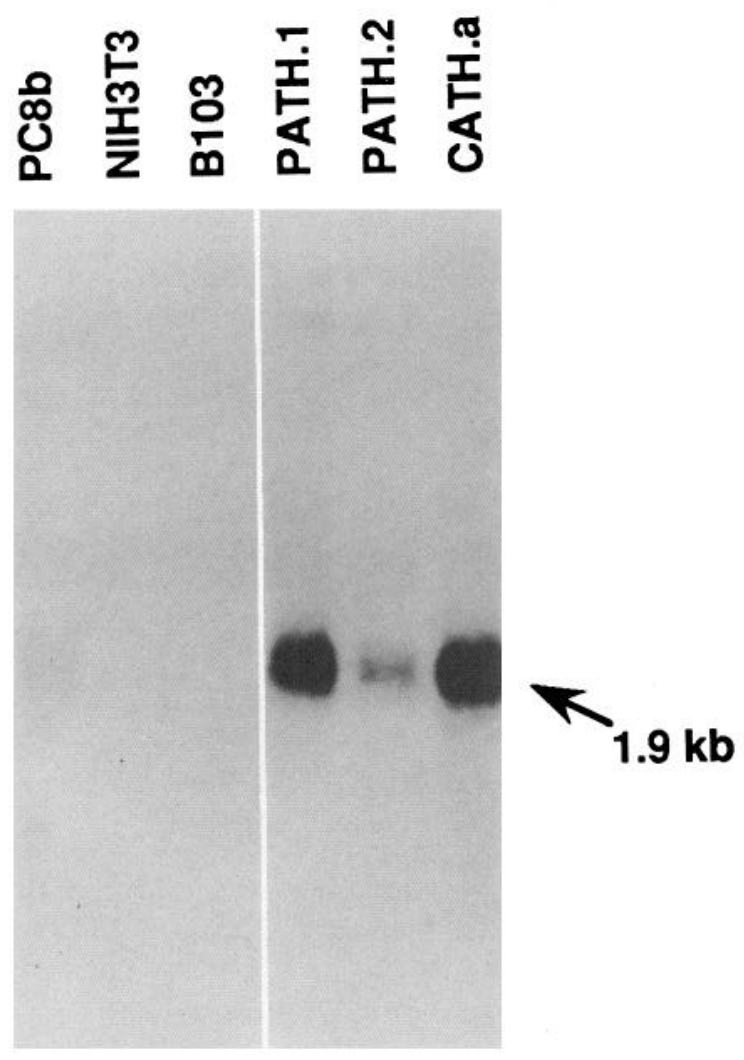

\section{$\begin{array}{llllll}1 & 2 & 3 & 4 & 5 & 6\end{array}$}

Figure 3. Northern analysis of TH RNA in cell lines: hybridization with TH cDNA ( $2 \mu \mathrm{g}$ of polyA ${ }^{+}$RNA was electrophoresed in each lane). Arrow indicates the correct size of the mRNA species. All lanes are from the same gel and blot.

demonstrating expression of TH protein in cells undergoing DNA replication. Non-catecholaminergic cell lines such as NIH3T3 and ATT20 failed to stain with either TH or Tag antiserum (data not shown).

TH mRNA expression in cell lines. To confirm biochemically that TH is expressed in these cells, a Northern analysis was performed on polyA ${ }^{+}$RNA. Figure 3 shows that all three THTag lines have a strong band at $1.9 \mathrm{~kb}$, the position of $\mathrm{TH}$ mRNA. As expected, PC8b cells show this band although at a reduced level compared to the TH-Tag lines, and the negative cell lines NIH3T3 and B103 (a CNS neuroblastoma) do not.

The three TH-Tag cell lines therefore contain abundant TH mRNA as judged by Northern blot analysis, and TH protein as judged by immunocytochemistry.

Activities of catecholaminergic enzymes in cell lines. To determine whether the TH protein is enzymatically active, we measured TH activity in vitro. Table 1 shows that PATH.1, PATH.2, and CATH.a have TH-specific activities of 776, 233, and $1129 \mathrm{pmol} / \mathrm{mg}$ protein $/ \mathrm{min}$, respectively. Since the next enzyme in the catecholamine biosynthetic pathway, dopa-decarboxylase, is found in most cells, the three cell lines should be capable of synthesizing the first major catecholamine, DA. To determine if the cells synthesize the second catecholamine in the pathway, $\mathrm{NE}$, we assayed for $\mathrm{DBH}$, which converts DA to NE. As Table 1 indicates, all three cell lines contain an active form of DBH, which suggests that these cells should also produce
Table 1. Activities of catecholamine biosynthetic enzymes

\begin{tabular}{lrl} 
Cell line & TH & DBH \\
\hline CATH.a & $1129 \pm 75(4)$ & $160 \pm 10(6)$ \\
PATH.1 & $778 \pm 280(4)$ & $140 \pm 40(6)$ \\
PATH.2 & $233 \pm 35(4)$ & $120 \pm 30(6)$ \\
PC8b & $37 \pm 5(4)$ & $320 \pm 50(3)$ \\
NIH3T3 & 0 & n.d.
\end{tabular}

Values are expressed as $\mathrm{pmol} / \mathrm{min} / \mathrm{mg}$ protein $\pm \mathrm{SD}(n)$; n.d., not determined. TH enzyme activities were determined essentially as described in Rittenhouse et al. (1988), and DBH activities were measured according to Sperk et al. (1980), both with slight modifications. See Materials and Methods.

$\mathrm{NE}$ if the required cofactors for $\mathrm{TH}$ and $\mathrm{DBH}$ are also present in the cells.

Catecholamine production in cell lines. To evaluate catecholamine production directly, DA and NE were measured in cell extracts by a reverse-phase HPLC system. As with the enzymatic assays, cells were plated in equal numbers and grown to similar densities before the catecholamines were extracted. High levels of both DA and NE can be detected in the cell extracts, while $\mathrm{E}$ was not detected even under conditions of high sensitivity. DA levels in all three cell types are higher than the NE levels, the ratio of DA to NE being approximately 1.9 for PATH.1, 2.5 for PATH.2, and 2.4 for CATH.a (Table 2). Analysis of the tissue-culture medium also revealed large amounts of the two catecholamines (Table 2) as well as of their degradation products (data not shown), suggesting a high basal secretion and turnover. Taken together with the enzyme assays, these results suggest that all three cell lines are noradrenergic. The lack of $\mathrm{E}$ in these cell lines is consistent with the absence of mRNA for PNMT, the enzyme required for the conversion of NE to E. Figure 4 shows that only RNA from the adrenal gland contains the $1.1 \mathrm{~kb}$ band specific to PNMT. None of the other cell lines, including PC12, were found to possess this RNA species.

Expression of a neuronal phenotype. The lines were assayed for the expression of NF, the intermediate filaments characteristic of neurons (Lazarides, 1982). NFs are composed of three separate proteins of $68 \mathrm{kDa}$ (light chain), $150 \mathrm{kDa}$ (medium chain), and $200 \mathrm{kDa}$ (heavy chain) (Hoffman and Lasek, 1975). Figure $5 a-c$ shows the immunocytochemical results with monoclonal antibodies against the medium chain of NF. Reaction product is clearly visible in patches near the periphery of all

Table 2. Catecholamine levels

\begin{tabular}{lcc} 
Cell line & DA & NE \\
\hline Intracellular & & \\
CATH.a & $182.2 \pm 12.1(4)$ & $77.2 \pm 2.5(4)$ \\
PATH.1 & $65.7 \pm 7.2(4)$ & $35.0 \pm 3.9(4)$ \\
PATH.2 & $19.5 \pm 3.4(4)$ & $7.8 \pm 0.8(4)$ \\
PC8b & $0.8 \pm 0.2(2)$ & $2.7 \pm 0.8(2)$ \\
NIH3T3 & 0 & 0 \\
Extracellular & & \\
CATH.a & $1542.9 \pm 217.5(2)$ & $260.1 \pm 38.3(2)$ \\
PATH.1 & $2128.0 \pm 83.6(2)$ & $546.8 \pm 24.9(2)$ \\
PATH.2 & $404.5 \pm 45.1(2)$ & $364.7 \pm 40.7(2)$ \\
PC8b & 0 & 0 \\
\hline
\end{tabular}

Values are expressed as pmol/mg cell protein $\pm \mathrm{SD}(n)$. Catecholamines were extracted by binding to acid-washed alumina and quantitated by HPLC as in Materials and Methods. 


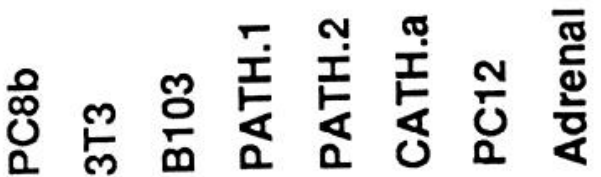

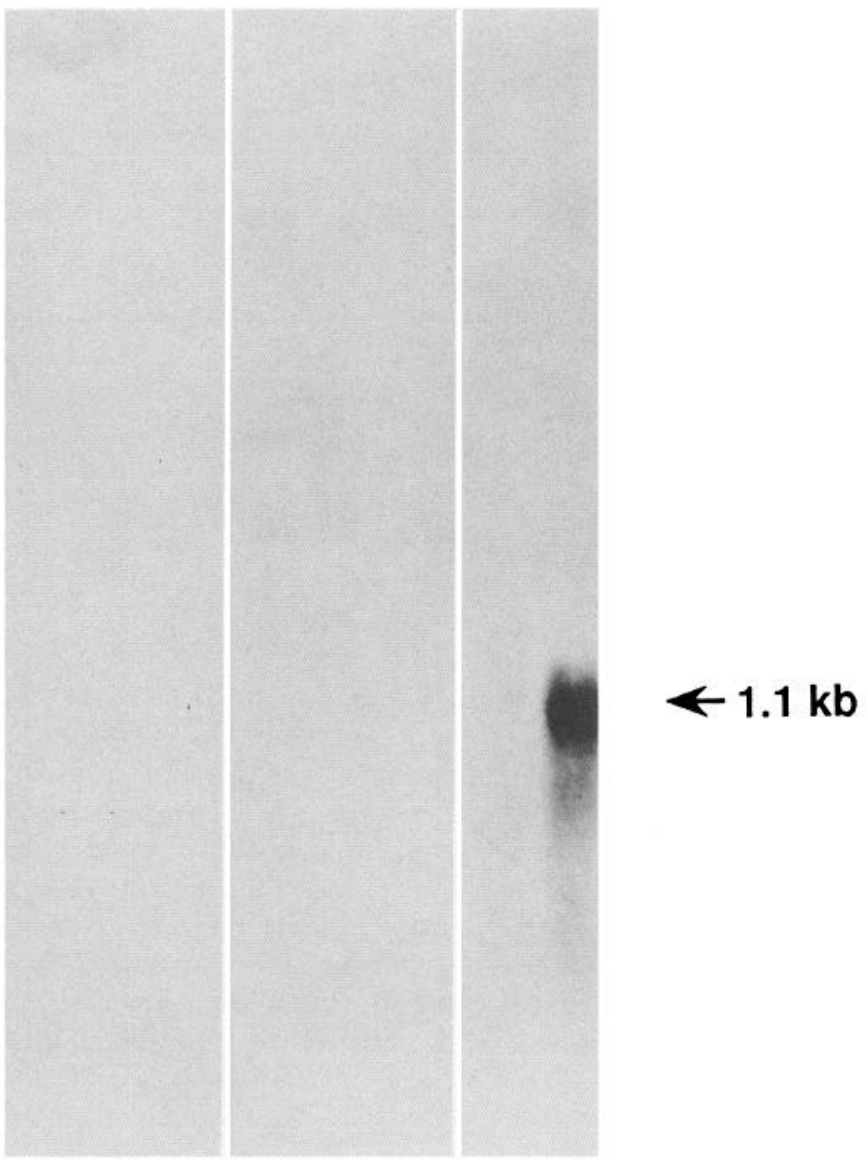

\section{$\begin{array}{llllllll}1 & 2 & 3 & 4 & 5 & 6 & 7 & 8\end{array}$}

Figure 4. Northern analysis of PNMT RNA in cell lines: hybridization with PNMT cDNA probe ( $2 \mu \mathrm{g}$ of polyA ${ }^{+}$RNA was electrophoresed in each level). Lane 8 contains RNA from mouse adrenal glands as a positive control. Arrow indicates the correct size of the mRNA species. All lanes are from the same gel and blot.

three cell types. The distribution of NF within cells is variable but when present it is always cytoplasmic. In contrast, when cells were stained with an antibody against GFAP, the intermediate filament characteristic of glial cells, no reaction was detected (Fig. $5 d-f$ ).

To confirm the presence of NF using an alternate approach, mRNA from the cell lines was analyzed for the presence of the NF light chain. In Figure 6 the two RNA species of $2.5 \mathrm{~kb}$ and $4.0 \mathrm{~kb}$ (Lewis and Cowan, 1985) encoding the light chain RNA are readily apparent in PATH.1 and CATH.a, while PATH.2 has less of the $68 \mathrm{kDa}$ NF RNA. Nevertheless, these data in conjunction with the antibody staining demonstrate that all three lines express NFs and lack GFAP, suggesting a neuronal or neuroendocrine origin. Control cell lines, NIH3T3 and B103, lack NF RNA.

Expression of synaptophysin. A polyclonal antibody against synaptophysin (p38) exhibits a similar and distinct staining pattern in all three lines. The staining is largely confined to a single, intense spot near the nucleus (Fig. 7). Control experiments showed no staining when primary antiserum was omitted or when a non-neuronal cell line, NIH3T3, was used.

Synaptophysin in neurons and endocrine cells is subject to differential modification by glycosylation and sulfation, resulting in multiple forms on SDS gels (Navone et al., 1986; RegnierVigouroux et al., 1991). To determine if indeed there were molecular differences in the protein between the three cell lines, a Western blot using the same polyclonal antibody was performed. As shown in Figure 8, all three cell lines contain p38 proteins (indicated by a bracket) that can be resolved into several closely migrating species. PATH.1 has a higher level of synaptophysin than PATH.2 and has fewer different isoforms that can be resolved on SDS gels. CATH.a has the highest concentration of p38 with several clearly distinguishable bands. In general, all three lines contain p 38 proteins that migrate more slowly than those derived from a control rat brain synaptosomal fraction.

\section{Discussion}

The development of TH-expressing brain tumors in transgenic mice carrying SV40 Tag directed by TH regulatory sequences demonstrates that the CNS catecholaminergic neurons are indeed susceptible to the effects of Tag. This is in contrast to the results obtained with the glucagon enhancer directing expression of Tag to neurons in the brainstem (Efrat et al., 1988). While Tag expression was detectable in specific brainstem neurons that are thought to be glucagon expressing, no tumors arose. In the same animals, Tag could be seen in the appropriate $\alpha$-cells of the endocrine pancreas as early as embryonic day 10 when those cells are first detected (Pictet and Rutter, 1972). At this site, the oncogene continued to be expressed throughout adulthood, leading to the formation of overt tumors by $9-12$ months. Since Tag-expressing neurons in the CNS failed to proliferate, a possible implication was that CNS neurons were not susceptible to the effects of an oncogene. Recent experiments with the GnRH promoter driving SV40 Tag have demonstrated that this is not the case for all neurons (Mellon et al., 1990). Not only did the transgenic mice develop tumors, but the neuronal cell lines isolated from such tumors continued to produce both GnRH and Tag. While it is likely that glucagon expression in the CNS is restricted to postmitotic neurons, the GnRH-expressing hypothalamic neurons, which are thought to arise from the olfactory placode, have been shown to express the hormone while still dividing (Schwanzel-Fukuda and Pfaff, 1989). These results might suggest that Tag needs to be expressed in a dividing cell in order to initiate transformation. This explanation is not entirely consistent with results using a PNMT-Tag transgene (Hammang et al., 1990). Retinal tumors were observed in these transgenic mice in amacrine cells that are thought to be postmitotic at the time when PNMT is first expressed. However, the cell type of origin for the amacrine cell cultures derived from these tumors is unclear since these cells did not produce PNMT. They also did not express other catecholaminergic properties, although the lack of TH and other catecholaminergic traits may be due to the fact that a significant percentage of PNMT-positive amacrine cells normally do not produce TH (Hadjiconstantinou et al., 1984; Park et al., 1986). Nevertheless, the lack of PNMT in cultured cells was surprising and was suggested by the authors to be due to a repression of the differentiated phenotype by Tag. Therefore, the issue as to whether a postmitotic neuron can be immortalized by the action of Tag remained unresolved in these experiments. 

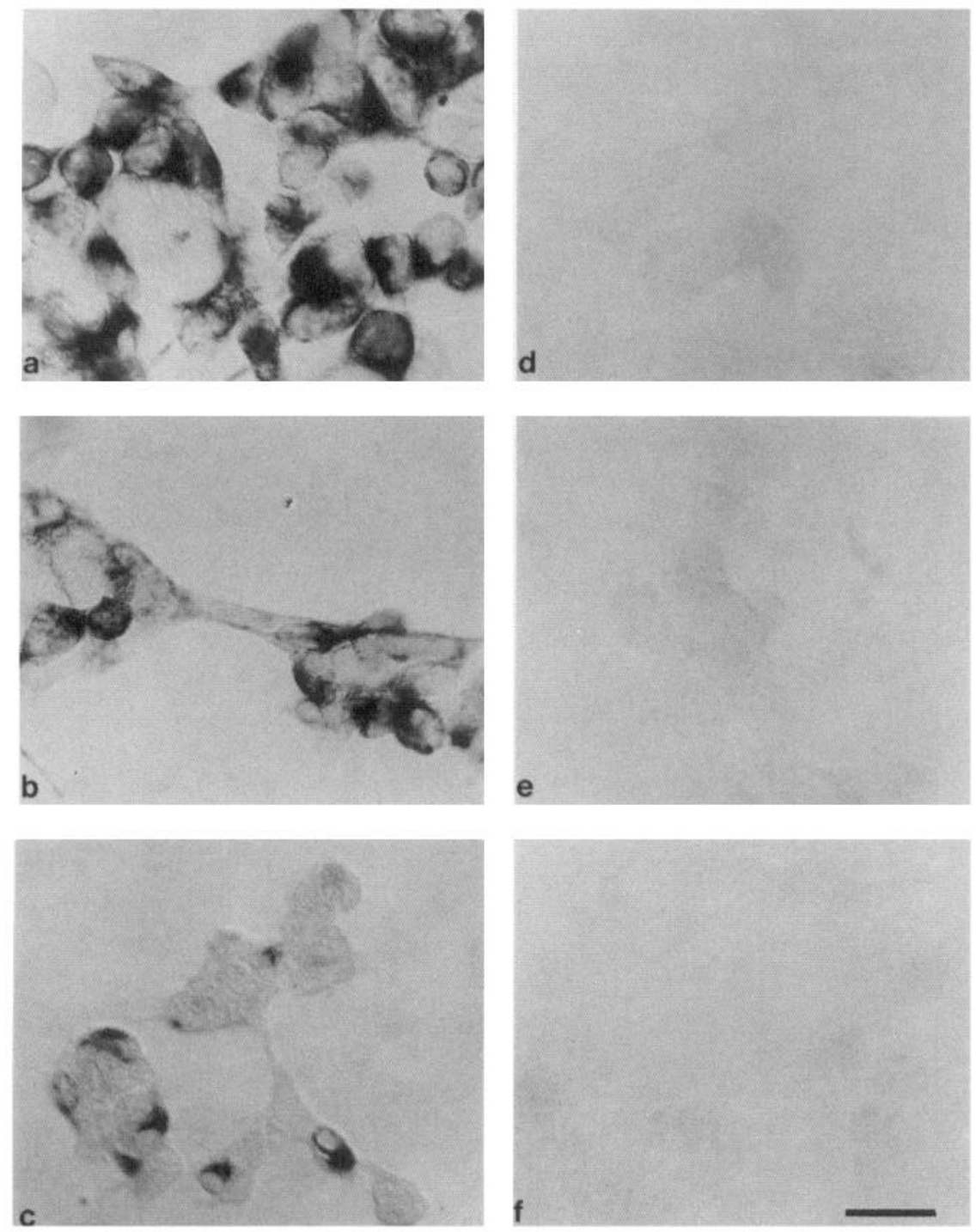

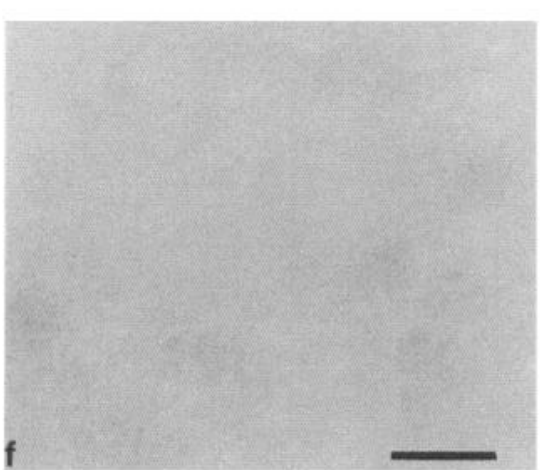

Figure 5. Expression of NF protein. $a-c$, Immunochemical staining with a monoclonal antibody against the medium chain of NF in CATH.a (a), PATH.1 $(b)$, and PATH.2 $(c) . d-f$, Staining with a monoclonal antibody against GFAP in CATH.a (d), PATH.1 $(e)$, and PATH. $2(f)$. Scale bar, $20 \mu \mathrm{m}$.
Our results clearly show that TH-producing CNS tumors can be obtained despite the fact that $\mathrm{TH}$ expression in the brain is observed only in postmitotic neurons in vivo (Specht et al., 1981). One possibility for the success of the TH promoter may be due to the fact that $\mathrm{TH}$ is an early marker of differentiated catecholaminergic neurons. In the rat $\mathrm{CNS}, \mathrm{TH}$ is first detected in cells at embryonic day 10.5 , within $1 \mathrm{~d}$ of the birth of these cells (Foster et al., 1985). Thus, even though TH is expressed by postmitotic neurons, the presence of Tag so early in development might allow the cell to reenter the cell cycle while maintaining TH expression. In contrast, expression of Tag late in development, with the glucagon or PNMT promoter constructs, may be incapable of driving a neuron back into the cell cycle after it has been withdrawn from the cycle for a number of days. This differential susceptibility of a neuron to oncogenesis based on its developmental status could also account for the lack of tumors in some tissues and their presence in others.

The observation that brain tumors only arose in adults and at various ages from 15 weeks to 8.5 months, but were always present in the same location in the brain even though Tag itself was present in other regions, implies two things: first, that Tag by itself is not sufficient to induce tumors in the brain, and second, that some cells in the midbrain or brainstem are more likely than others to undergo complete transformation.

The observation that SV40 Tag requires additional transforming events in order to cause neoplasia is well established. The multistep process hypothesized for tumorigenesis (Foulds, 1958) has been strongly supported by experiments with primary cells in tissue culture (Land et al., 1983; Yancopoulos et al., 1985) and with transgenic mice in vivo (Hanahan, 1985; Mahon et al., 1987; Sinn et al., 1987). The lack of brain tumors with the glucagon-Tag transgene (Efrat et al., 1988) could be due to the smaller numbers of glucagon-positive cells as compared to the number of TH-positive cells. The small number of glucagon-positive cells would reduce the number of potential targets for subsequent "hits" needed for full transformation.

The fact that TH-producing tumors always arose in the same location in the brain demonstrates that cells in this area are more prone to neoplasia. Possibly, Tag is expressed earlier in development in these susceptible cells. Alternatively, it may be that the TH-expressing cells of this region can transcribe Tag more efficiently because of the presence of appropriate transactivating factors that would efficiently activate the TH promoter as compared to non-TH-expressing neurons in other brain 

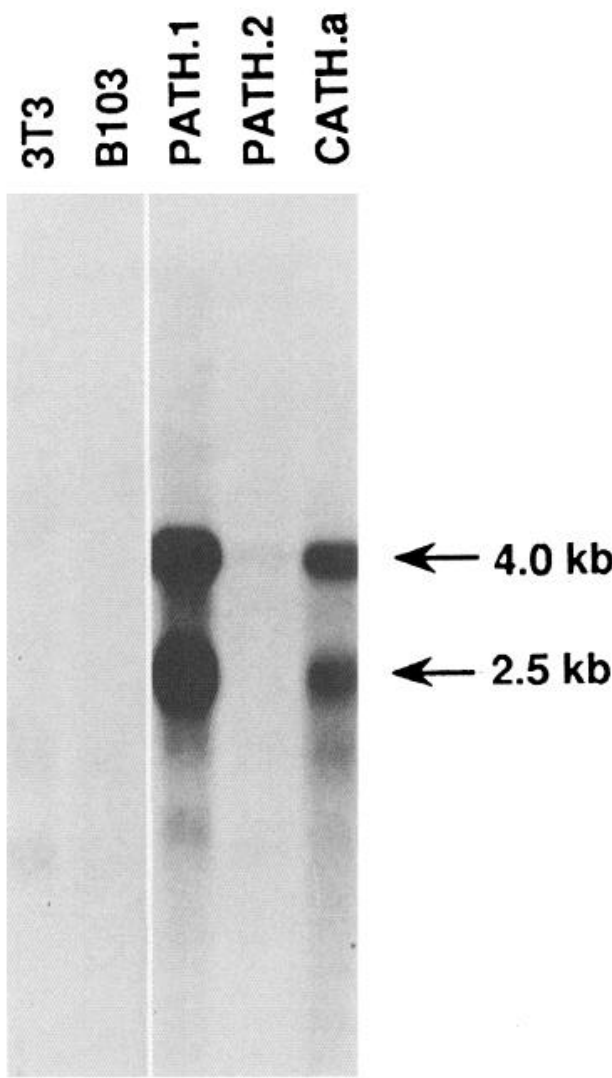

\section{$\begin{array}{lllll}1 & 2 & 3 & 4 & 5\end{array}$}

Figure 6. Northern analysis of NF RNA in cell lines. Lanes contain $2 \mu \mathrm{g}$ of polyA $\mathrm{A}^{+} \mathrm{RNA}$ from cell lines and were hybridized with a riboprobe against NF light chain mRNA. Arrows mark the sizes of the two mRNA species of the light chain gene of NF. All lanes are from the same gel and blot.

regions. This difference in Tag levels might account for the relative ease with which transformation is accomplished in $\mathrm{TH}-$ expressing cells.

The absence of Tag staining in some TH-expressing tissues such as OB and SCG is likely to reflect the lack of appropriate tissue-specific elements in $773 \mathrm{bp}$ of TH upstream region. A similar pattern of Tag expression was found in transgenic mice in which $2.8 \mathrm{~kb}$ of $5^{\prime}$ TH DNA was used (C. Suri and D. M. Chikaraishi, unpublished observations). While these transgenic mice developed CNS tumors similar to the $-773 \mathrm{TH}-\mathrm{Tag}$ mice, they also failed to express Tag in the OB and SCG. Recently, Kaneda et al. (1991), using the entire coding region of the human TH gene including $2.5 \mathrm{~kb}$ of $5^{\prime}$ flanking DNA and $0.5 \mathrm{~kb}$ of $3^{\prime}$ flanking DNA, demonstrated a strong expression in appropriate brain regions and adrenal glands as well as inappropriate expression in CNS regions like the striatum and hippocampus. In fact, further in situ and immunohistochemical analyses extended the areas of ectopic expression in the CNS (Nagatsu et al., 1991). Unfortunately, expression in the OB and SCG was not reported in these studies. In contrast, a longer 5 ' flanking region $(4.8 \mathrm{~kb})$ of the rat TH gene appears to contain all the elements for correct tissue-specific expression in transgenic mice (Banerjee et al., 1992). Creation of transgenic mice bearing the $4.8 \mathrm{TH}-\mathrm{Tag}$ construct was in fact attempted but only 1 of 47 pups carried the transgene and that one lineage was nonexpressing, suggesting
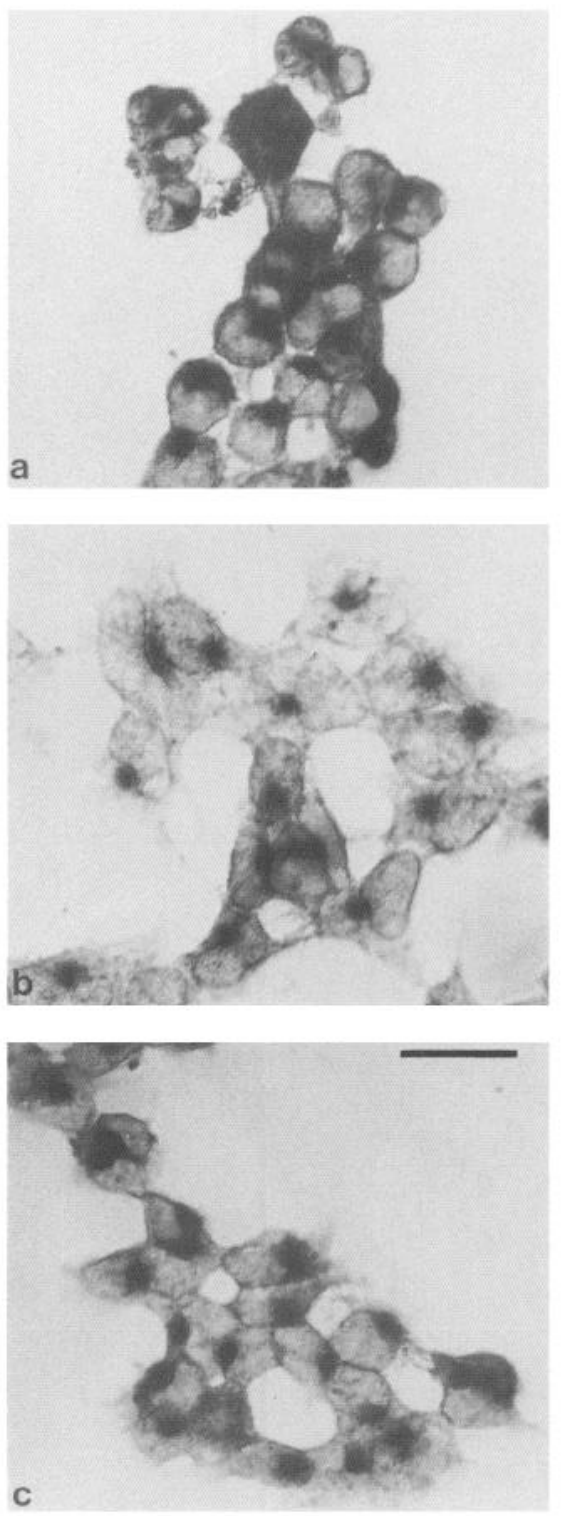

Figure 7. Presence of synaptophysin in the TH-Tag cell lines: immunocytochemical staining in CATH.a (a), PATH.1 (b), and PATH.2 (c). Scale bar, $20 \mu \mathrm{m}$.

that the presence of the transgene may have had a deleterious effect on the development of the fetus (Suri and Chikaraishi, unpublished observations).

Several lines of evidence demonstrate that CATH.a, PATH.1, and PATH.2 are noradrenergic. They synthesize active forms of the enzymes TH and DBH and produce the catecholamines DA and NE. The activities of the two enzymes are similar to those in the PC12 cell line. The activity of TH in $\mathrm{PC} 12$ cells, as initially reported, was $39 \pm 5 \mathrm{pmol} / \mathrm{min} / \mathrm{mg}$ protein (Greene and Tischler, 1976), which is 6-30-fold less than in the THTag lines. DBH, on the other hand, has an activity level of 806 $\pm 84 \mathrm{pmol} / \mathrm{min} / \mathrm{mg}$ protein in $\mathrm{PC} 12$ cells, which is approximately five- to sevenfold more than in the TH-Tag lines. The levels of DA and NE in PC12 cells are $16.6 \pm 1.7$ and $6.1 \pm 6$ $\mathrm{nmol} / \mathrm{mg}$ protein, respectively, which are higher than in the $\mathrm{TH}-$ Tag lines. This may be because the TH-Tag lines secrete large amounts of catecholamines into the tissue culture medium.

The presence of NFs, the intermediate filaments in neurons, 


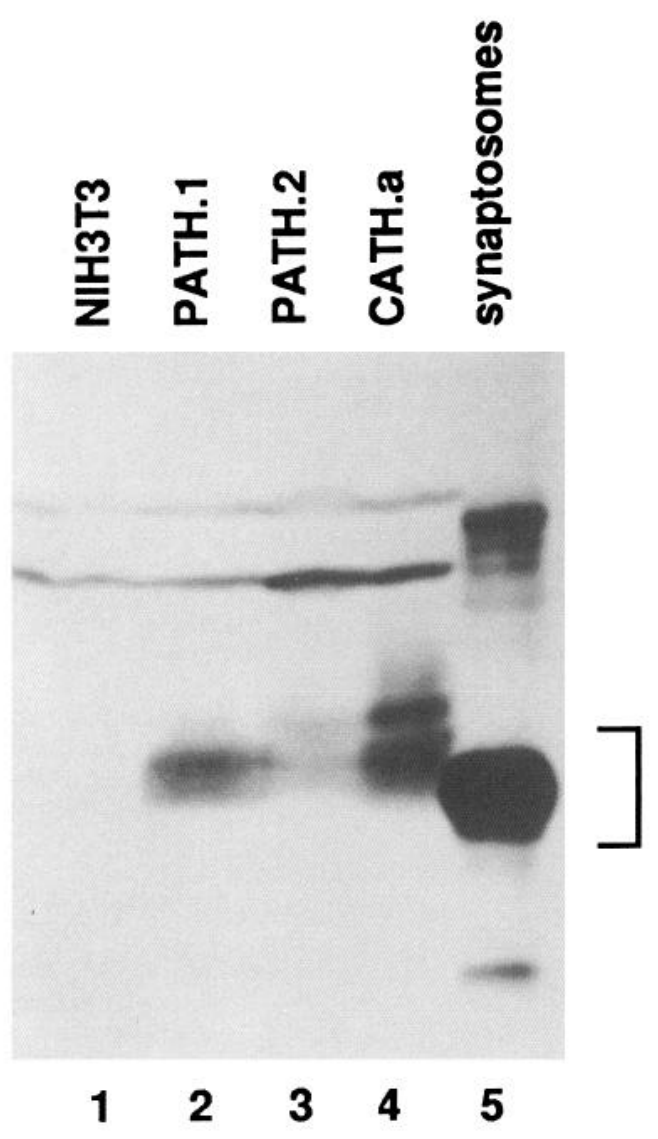

Figure 8. Presence of synaptophysin in the TH-Tag cell lines: Western analysis with synaptophysin antibody. Each lane contains $67 \mu \mathrm{g}$ of total protein from the following: NIH3T3 (lane 1), PATH.1 (lane 2), PATH.2 (lane 3), CATH.a (lane 4), and a rat brain synaptosomal fraction (lane 5). Bracketed region shows the position of synaptophysin from rat brain.

and the absence of GFAP, characteristic of glial cells, imply that the TH-Tag cell lines are neuronal in origin. The presence of synaptophysin or $\mathrm{p} 38$ in the TH-Tag lines suggests the existence of synaptic vesicles, although the presence of vesicles needs to be confirmed by ultrastructural analysis. It is interesting that the apparent molecular weight of p38 in all three cell lines is higher than in the rat brain synaptosomal preparation. This may be due to different posttranslational modifications in the transformed cells, since other neuroendocrine tumors and neuroblastomas also exhibit these differences (Weidenmann and Huttner, 1989).

Synaptophysin or p38 is an integral membrane protein with a molecular weight of $38 \mathrm{kDa}$. It is inserted in the membranes of small vesicles found only in neurons and neuroendocrine cells (Navone et al., 1986). In neurons these vesicles have been shown to function as storage sites for non-peptidergic neurotransmitters and to participate in their regulated release via exocytosis. In endocrine cells the function of p38-containing vesicles is not well understood (Johnston et al., 1989). The pattern of staining for synaptophysin in our cells is very similar to that in PC12 cells, where the majority of staining has been shown to be centered about the Golgi complex (Johnston et al., 1989). If synaptophysin is incorporated into vesicles they may tend to pool near the Golgi complex, their site of synthesis. Since PATH and CATH.a lack neurites under normal culture conditions, they may lack the machinery necessary to transport vesicles to the periphery and hence accumulate more vesicles over the Golgi complex.

The small cell size and the large nuclear to cytoplasmic ratio suggest that the three lines have originated from relatively immature cells. The PATH lines are likely to have arisen from precursors in the chromaffin lineage in the adrenal medulla. The lack of $E$ is consistent with the immortalization of a precursor cell, since immature sympathoadrenal cells tend to be noradrenergic. The noradrenergic phenotype of CATH.a is consistent with an origin in the NE neurons of the brainstem mainly located in the locus coeruleus and lateral tegmental area. However, a more rigorous biochemical and physiological examination is required before the origin can be fully established, since it may be that some dopaminergic cells of the midbrain express NE transiently during development (Choi et al., 1991). It would be of interest to determine whether CATH.a bears receptors for GABA (Cedarbaum and Aghajanian, 1976), 5-HT (Segal, 1979), opiates (Atweh and Kuhar, 1977), and NE (Aghajanian et al., 1977), as has been demonstrated for locus coeruleus neurons.

In conclusion, our results demonstrate that promoter directed oncogenesis in transgenic animals can be used to establish CNS cell lines from postmitotic neurons. Since our cell lines retain high levels of catecholamine expression, they should be useful for a variety of studies involving gene regulation and transplantation and should serve as good sources for the isolation of tissue-specific transcription factors.

\section{References}

Aghajanian GK, Cedarbaum JM, Wang RY (1977) Evidence for norepinephrine-mediated collateral inhibition of locus coeruleus neurons. Brain Res 136:570-577.

Amano T, Richelson E, Nirenberg M (1972) Neurotransmitter synthesis by neuroblastoma clones. Proc Natl Acad Sci USA 69:258263.

Atweh SF, Kuhar MJ (1977) Autoradiographic localisation of opiate receptors in rat brain, II. The brain stem. Brain Res 129:1-12.

Baetge EE, Behringer RR, Messing A, Brinster RL, Palmiter RD (1988) Transgenic mice express the human phenylethanolamine $N$-methyltransferase gene in adrenal medulla and retina. Proc Natl Acad Sci USA 85:3648-3652.

Banerjee SA, Hoppe P, Brilliant M, Chikaraishi DM (1992) 5' flanking sequences of the rat tyrosine hydroxylase gene target accurate tissuespecific, developmental, and transsynaptic expression in transgenic mice. J Neurosci 12:4460-4467.

Behringer RR, Peschon JJ, Messing A, Gartside CL, Hauschka SD, Palmiter RD, Brinster RL (1988) Heart and bone tumors in transgenic mice. Proc Natl Acad Sci USA 85:2648-2652.

Bjorklund A, Lindvall O (1984) In: Handbook of chemical neuroanatomy, Vol 2, Classical neurotransmitters in the CNS, Pt I (Bjorklund A, Hokfelt T, eds), pp 55-111. Amsterdam: Elsevier.

Cambi F, Fung B, Chikaraishi DM (1989) 5' flanking DNA sequences that direct cell-specific expression of rat tyrosine hydroxylase. J Neurochem 53:1656-1659.

Cedarbaum JM, Aghajanian GK (1976) Noradrenergic neurons of the locus coeruleus: inhibition by epinephrine and activation by the $\alpha$-antagonist piperoxane. Brain Res 112:413-419.

Cepko CL (1989) Immortalisation of neural cells via retrovirus-mediated oncogene transduction. Annu Rev Neurosci 12:47-65.

Chen CW, Thomas CA Jr (1980) Anal Biochem 101:339-341.

Choi HK, Won LA, Kontur PJ, Hammond DN, Fox AP, Wainer BH, Hoffmann PC, Heller A (1991) Immortalisation of embryonic mesencephalic dopaminergic neurons by somatic cell fusion. Brain Res 552:67-76.

Cory S, Adams JM (1988) Transgenic mice and oncogenesis. Annu Rev Immunol 6:25-48.

Crawford GD Jr, Le W-D, Smith RG, Xie W-J, Stefani E, Appel SH (1992) A novel N18TG2 $\times$ mesencephalon cell hybrid expresses properties that suggest a dopaminergic cell line of substantia nigra origin. J Neurosci 12:3392-3398. 
Davis LG, Hennighausen L, Woychik R, Leder A, Tepler I, Kuo A, Stewart TA, Leder P (1987) In: Accomplishments in cancer research (Fortner JG, ed), pp 110-118. Philadelphia: Lippincott.

Efrat S, Teitelman G, Anwar M, Ruggiero D, Hanahan D (1988) Glucagon gene regulatory region directs oncoprotein expression to neurons and pancreatic $\alpha$ cells. Neuron 1:605-613.

Fader D, Lewis EJ (1990) Interaction of cyclic AMP and cell-cell contact in the control of tyrosine hydroxylase RNA. Mol Brain Res $8: 25-29$.

Fiers W, Contreras R, Haegeman G, Rogiers R, Van de Voorde A, Van Hwverswyn H, Van Herreweghe J, Volckaert G, Ysebaert M (1978) Complete nucleotide sequence of SV40 DNA. Nature 273:113-120.

Foster GA, Schultzberg M, Goldstein M, Hokfelt T (1985) Ontogeny of phenylethanolamine $N$-methyltransferase- and tyrosine hydroxylase-like immunoreactivity in presumptive adrenaline neurons of the foetal rat central nervous system. J Comp Neurol 236:348-381.

Foulds L (1958) The natural history of cancer. J Chronic Dis 8:2-37.

Fredericksen K, Jat PS, Valtz N, Levy D, McKay RGD (1988) Immortalisation of precursor cells from the mammalian CNS. Neuron $1: 439-448$.

Fung B, Yoon SO, Chikaraishi DM (1992) Sequences that direct rat tyrosine hydroxylase expression. J Ncurochem 58:2044-2052.

Gizang-Ginsberg E, Ziff EB (1990) Nerve growth factor regulates tyrosine hydroxylase gene transcription through a nucleoprotein complex that contains c-fos. Genes Dev 4:477-491.

Greene LA, Tischler AS (1976) Establishment of a noradrenergic clonal line of rat adrenal pheochromocytoma cells which respond to nerve growth factor. Proc Natl Acad Sci USA 73:2424-2428.

Hadjiconstantinou M, Mariani AP, Panula P, Joh TH, Neff NH (1984) Immunohistochemical evidence for epinephrine-containing retinal amacrine cells. Neuroscience 13:547-551.

Hammang JP, Baetge EE, Behringer RR, Brinster RL, Palmiter RD, Messing A (1990) Immortalised retinal neurons derived from SV40 T-antigen-induced tumors in transgenic mice. Neuron 4:775-782.

Hanahan D (1985) Heritable formation of pancreatic $\beta$-cell tumors in transgenic mice expressing recombinant insulin/simian virus 40 oncogenes. Nature 315:115-122.

Hanahan D (1989) Transgenic mice as probes into complex systems. Science 246:1265-1275.

Hoffman PN, Lasek R (1975) The slow component of axonal transport. Identification of major structural polypeptides of the axon and their generality among mammalian neurons. J Cell Biol 66:351-366.

Hogan B, Constantini F, Lacy E (1986) In: Manipulating the mouse embryo: a laboratory manual. Cold Spring Harbor, NY: Cold Spring Harbor Laboratory.

Jenkins NA, Copeland NG (1989) In: Important advances in oncology (DeVita VT, Hellum S, Rosenberg SA, eds), pp. 61-77. Philadelphia: Lippincott.

Johnston PA, Cameron PL, Stukenbrok H, Jahn R, DeCamilli P, Sudhof TC (1989) Synaptophysin is targeted to similar microvesicles in CHO and PC12 cells. EMBO 8:2863-2872.

Kaneda N, Sasaoka T, Kobayashi K, Kiuchi K, Nagatsu I, Kurusawa Y, Fujita K, Yokoyama M, Nomura T, Katsuki M, Nagatsu T (1991) Tissue-specific and high-level expression of the human tyrosine hydroxylase gene in transgenic mice. Neuron 6:583-594.

Land H, Parada LF, Weinberg RA (1983) Tumorigenic conversion of primary embryo fibroblasts requires at least two cooperating oncogenes. Nature 304:596-602.

Lazarides E (1982) Intermediate filaments: a chemically heterogenous developmentally regulated class of proteins. Annu Rev Biochem 51: 219-245.

Lee HJ, Hammond DN, Large TH, Roback JD, Sinn JA, Brown DA, Otten UH, Wainer BH (1990) Neuronal properties and trophic activities of immortalised hippocampal cells from embryonic and young adult mice. J Neurosci 10:1779-1787.

Lendahl U, McKay RDG (1990) The use of cell lines in neurobiology. Trends Neurosci 13:132-137.

Lewis EJ, Harrington VA, Chikaraishi DM (1987) Transcriptional regulation of the tyrosine hydroxylase gene by glucocorticoids and cyclic AMP. Proc Natl Acad Sci USA 84:3550-3554.

Lewis SA, Cowan NJ (1985) Genetic evolution and expression of the 68,000-molecular weight neurofilament protein: isolation of a cloned cDNA probe. J Cell Biol 100:843-850.

Lowry OH, Rosebrough NJ, Farr AL, Randall RJ (1951) Protein measurement with the Folin phenol reagent. J Biol Chem 193:265275 .
Mahon KA, Chepelinsky AB, Khilian JS, Overbeek PA, Piatigorsky J, Westphal H (1987) Oncogenesis of the lens in transgenic mice. Science 235:1622-1628.

Maniatis T, Fritsch EF, Sambrook J (1982) In: Molecular cloning: a laboratory manual. Cold Spring Harbor, NY: Cold Spring Harbor Laboratory.

Mellon PL, Windle JJ, Goldsmith PC, Padula CA, Roberts JL, Weiner RI (1990) Immortalisation of hypothalamic $\mathrm{GnRH}$ neurons by genetically targeted tumorigenesis. Neuron 5:1-10.

Murphy D, Bishop A, Rindi G, Murphy MN, Stamp GWH, Hanson J, Polak JM, Hogan B (1987) Mice transgenic for a vasopressin-SV40 hybrid oncogene develop tumors of the endocrine pancreas and the anterior pituitary. Am J Pathol 129:552-566.

Nagatsu I, Yamada K, Karasawa N, Sakai M, Takeuchi T, Kaneda N, Sasaoka T, Kobayashi K, Yokayama M, Nomura T, Katsuki M, Fujita $K$, Nagatsu $T$ (1991) Expression in brain sensory neurons of the transgene in transgenic mice carrying human tyrosine hydroxylase gene. Neurosci Lett 127:91-95.

Navone F, Jahn R, DiGioia G, Stukenbrok H, Greengard P, DeCamilli P (1986) Protein p38: an integral membrane protein specific for small vesicles of neurons and neuroendocrine cells. J Cell Biol 103: 2511-2527.

Park DH, Teitelman G, Evinger MJ, Woo JI, Ruggiero DA, Albert VR, Baetge EE, Pickel VM, Joh TH (1986) Phenylethanolamine $N$-methyltransferase-containing neurons in rat retina: immunohistochemistry, immunochemistry and molecular biology. J Neurosci 6:11081113.

Pictet R, Rutter WJ (1972) In: Handbook of physiology, Sec 7 (Steiner DF, Freinkel N, eds), p 25. Washington, DC: American Physiological Society.

Regnier-Vigouroux A, Tooze SA, Huttner WB (1991) Newly synthesized synaptophysin is transported to synaptic-like microvesicles via constitutive secretory vesicles and the plasma membrane. EMBO J 10:3589-3601.

Renfranz PJ, Cunningham MG, McKay RDG (1991) Region-specific differentiation of the hippocampal stem cell line HiB5 upon implantation into the developing mammalian brain. Cell 66:713-729.

Rittenhouse AR, Schwarzschild MA, Zigmond RE (1988) Both synaptic and antidromic stimulation of neurons in the rat superior cervical ganglion acutely increase tyrosine hydroxylase activity. Neuroscience $25: 207-215$.

Rothman TP, Specht LA, Joh TH, Teitelman G, Pickei VM, Gershon MJ, Reis DJ (1980) Catecholamine biosynthetic enzymes are expressed in replicating cells of the peripheral but not the central nervous system. Proc Natl Acad Sci USA 77:6221-6225.

Ryder EF, Snyder EY, Cepko CL (1990) Establishment and characterisation of multipotent neural cell lines using retrovirus vectormediated oncogene transfer. J Neurobiol 21:365-375.

Schubert D, Heinemann S, Carlisle W, Tarikas H, Kumes B, Patrick J, Steinbach JII, Culp W, Brandt BL (1974) Clonal cell lines from the rat central nervous system. Nature 249:224-229.

Schwanzel-Fukuda M, PfaffDW (1989) Origin ofluteinizing hormonereleasing hormone neurons. Nature 338:161-163.

Segal (1979) Serotonergic innervation of the locus coeruleus from the dorsal raphe and its action on responses to noxious stimuli. J Physiol (Lond) 286:401-415.

Sinn E, Muller W, Pattengale P, Tepler I, Wallace R, Leder P (1987) Coexpression of MMTV/v-Ha-ras and MMTV/c-myc genes in transgenic mice: synergistic action of oncogenes in vivo. Cell 49:465-475.

Snyder EY, Deitcher DL, Walsh C, Arnold-Aldea S, Hartwieg EA, Cepko CL (1992) Multipotent neural cell lines can engraft and participate in development of mouse cerebellum. Cell 68:33-51.

Specht LA, Pickel UM, Joh TH, Reis DJ (1981) Light-microscopic immunocytochemical localisation of tyrosine hydroxylase in prenatal rat brain. I. early ontogeny. J Comp Neurol 199:233-253.

Spengler BA, Biedler JL, Helson L, Freedman LS (1973) Morphology and growth, tumorigenicity, and cytogenetics of human neuroblastoma cells established in vitro. In Vitro 8:410.

Sperk G, Galhaup I, Schlogl E, Hortnagl H, Hornykiewicz O (1980) A sensitive and reliable assay for dopamine $\beta$-hydroxylase in tissue. J Neurochem 35:972-976.

Tank WE, Bowyer JF, Carlson CD, Fossom LH, Signs SA (1990) In: Catecholamine Genes (Joh TH, ed), pp 81-99. New York: Liss.

Waymire JC, Gilmer-Waymire K (1978) Adrenergic enzymes in cultured mouse neuroblastoma: absence of detectable aromatic- $L$-amino-acid decarboxylase. J Neurochem 31:693-698. 
Weidenmann B, Huttner WB (1989) Synaptophysin and chromogranins/secretogranins-widespread constituents of distinct types of neuroendocrine vesicles and new tools in tumor diagnosis. Virchows Archiv [Cell Pathol] 58:95-121.

Windle JJ, Weiner RI, Mellon PL (1990) Cell lines of the pituitary gonadotrope lineage derived by targeted oncogenesis in transgenic mice. Mol Endocrinol 4:597-603.
Yancopoulos GD, Nisen PD, Tesfaye A, Kohl NE, Goldfarb MP, Alt FW (1985) N-myc can cooperate with ras to transform normal cells in culture. Proc Natl Acad Sci USA 82:5455-5459.

Yoon SO, Chikaraishi DM (1992) Tissue-specific transcription of the rat tyrosine hydroxylase gene requires synergy between an AP-1 motif and an Overlapping E box-containing dyad. Neuron 9:55-67. 